\title{
The diet of the Tristan da Gunha Islanders
}

\author{
By ELAINE C. TAYLOR \\ Scottish Home and Health Department, Glasgow, C I
}

AND
DOROTHY F. HOLLINGSWORTH AND MARGARET A. CHAMBERS*
Ministry of Agriculture, Fisheries and Food, London, $S W_{\mathrm{I}}$
(Received 29 Fuly 1965-Accepted I4 February 1966)

\begin{abstract}
I. An assessment of the Islanders' food consumption on Tristan da Cunha before the volcanic eruption of 1961 was made (Part I). The mean daily intake of energy was 2030 kcal per person and the calories derived from protein, fat, carbohydrate and alcohol accounted for $21,26,50$ and $3 \%$ respectively of the total calorie intake, the proportion of calories derived from protein being about twice that found in other types of diet. 2. The weekly food intake of thirty-seven families resident at Calshot, Hants, was measured in July $1963,3-4$ months before the Islanders left England to return to Tristan da Cunha (Part 2). The mean intake of energy was $1750 \mathrm{kcal}$ per person per day and the calories derived from protein, fat and carbohydrate accounted for about 12,41 and $47 \%$ respectively of total calorie intake, proportions similar to those found in present-day British diets. The proportion of other nutrients in relation to calories also resembled those in British diets, except for vitamin $A$ and ascorbic acid, which were relatively low in the Tristan diet. 3. A comparison of the results for the Islanders with those for a sample of households surveyed for the National Food Survey was made. The Islanders consumed less of all nutrients, and the average energy value met only $65 \%$ of estimated requirements compared with $108 \%$ in the British sample. 4 . Details of foods consumed and of the Islanders' food patterns and preferences are given. There is some evidence that the Tristanians did not like their former staple foods, potatoes and fish, as available in England, though at the time of the survey they had not appreciably switched to the British staple, bread. 5. The relatively low food intake reported in this study conforms with that recorded in the Norwegian investigation of 1937-8 (Henriksen \& Oeding, 1946) and with calculations of island food supplies before $196 \mathrm{I}$ (Part I). 6. Possible explanations for the low food intake are discussed. It is suggested that the Islanders may not be very active and that energy balance studies on individuals who have returned to Tristan da Cunha might throw some light on the results of this survey.
\end{abstract}

Among nutritionists the diet of the inhabitants of 'Tristan da Cunha has been something of a legend for about a quarter of a century. For example, in their discussion on dental caries in the first edition of The Englishman's Food, Drummond \& Wilbraham (1939) described the changes in the diet of this isolated community between a visit of HMS Carlisle to the Island in 1932, reported by Sampson (1932), and a second visit in 1937, reported by Barnes (1937). On subsequent occasions, in 1952 and 1955, British Royal Naval dental officers again took part in surveys on teeth and diet on the Island (King-Turner \& Davies, I956) and the general conclusion was that between the 1932 and the 1955 visits teeth had greatly deteriorated and the diet had changed from 'potatoes, fish, eggs, a little milk and vegetables, with hardly any cereals' to a diet still based upon potatoes and fish, but by that time considerably supplemented by flour, sugar, jam and small quantities of biscuits, rice, canned fruit, sweets and canned

* Present address: Division of Human Physiology, National Institute for Medical Research, Hampstead, London, $\mathrm{NW}_{3}$. 
milk obtained from the Tristan da Cunha Development Company's canteen. The reports on the diet in the r 93 os are in conformity with those of Henriksen \& Oeding (1946) and Woolley (1946). Woolley's description of the diet (based on residence on the island as Medical Officer and Governor between 1942 and 1944) was as follows:

'The staple food is the potato. For periods of weeks together, it is common for people to eat nothing but potatoes in various forms-boiled, fried in penguin fat, or made into leaden boiled puddings. This is supplemented by fish when the weather allows it to be caught, and rarely by meat.'

'Eggs of sea-birds are eaten in season, and domestic poultry produce a few eggs during the spring and summer months. The milk supply used to be grossly inadequate, sufficient for tea, but little else, and entirely absent from the diet during the winter. Some children had never tasted it. Following simple reorganisation of grazing, this milk shortage has been remedied temporarily, and in 1944 supplies were adequate for those civilians owning cows....

'The only vegetable grown in any quantity is the pumpkin. During the late summer, cranberries and a few apples are obtained. The remainder of the diet consists of small quantities of luxuries such as sugar, tea, tinned foods, obtained from charitable sources in the annual "mail".'

The only quantitative information we have been able to find about the diet of the I 930 s is that obtained during the course of the Norwegian Scientific Expedition in 1937-8 reported by Henriksen \& Oeding (1946). In this survey, records were obtained of the total food consumption of three families, each for a year, and of the recipes used, and the calorie value of each annual diet was calculated. The three estimates were per head per day $1237 \mathrm{kcal}$, I $670 \mathrm{kcal}$ and $775 \mathrm{kcal}$ plus in each, it was suggested, $200 \mathrm{kcal}$ from seabirds' fat, apples, vegetables and imported food. As in all other accounts, the chief articles of food were potatoes and fish, supplemented by some mutton and beef, and according to season, seabirds' eggs, young seabirds, varying quantities of milk and berries as well as the seabirds' fat, apples, vegetables and imported foods as already mentioned.

Samuels (1963) has given a general account of the diet of the Islanders immediately before they left Tristan da Cunha in 196r. He confirmed that the basic diet was then the same as that described by Henricksen \& Oeding (1946) and Woolley (1946), but provided supplementary information on the feeding of infants who 'although mainly breast-fed until perhaps 2 years of age, had early (at 2 to 3 months old) supplements of potatoes and boiled fish, but in the past two to three years breast-feeding has tended to decline and has been replaced by bottle feeds of sweetened condensed milk.' Samuels also stated that since the inception of the canteen in Navy occupation days 'the Islanders' eating habits have been modified, and instead of the perfect teeth reported on by Soggnaes (1954) [relating to the 1930s] there is now widespread and extensive caries and gingivitis'.

The eruption of the volcano on Tristan da Cunha in 1961 and the consequent presence of the Islanders in England from 1961 to 1963 provided an opportunity to study this inbred group, which was initially thought to enjoy a high standard of health (Henriksen \& Oeding, 1946). On their arrival in England it was revealed that in fact 
the standard was low, and the Medical Research Council appointed a working party to make a thorough investigation of the Islanders' health (Lewis, I963).

There was serious dental and periodontal disease (Holloway, James \& Slack, 1963). In this connexion it is of interest that, between 1955 and 1962 , eleven samples of Tristan drinking water were examined in the Laboratory of the Government Chemist for fluorine and were found to contain the low concentration of O.I ppm (W. F. Waters, personal communication). The Islanders were anaemic and many of them were infested with roundworms (Thacker, ${ }_{1963}$ ). Almost half suffered from bronchospasm and many of the asthmatics were examined in England; genetic factors were considered to play an important part in the incidence of asthma (Citron \& Pepys, 1964). There was an unusually high prevalence of congenital abnormalities (Black,

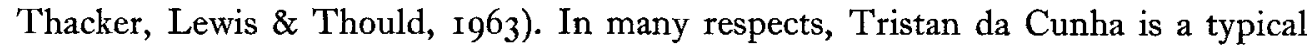
underdeveloped country, but the Islanders showed no obvious signs of malnutrition and there was only one case of active tuberculosis on arrival in England (Sakula, 1963).

As a result of the Medical Research Council's effort, the Islanders were cured of the conditions which could be treated. For example, new standards of oral hygiene were introduced, the worms were eliminated, and in the majority of the Islanders the haemoglobin was rapidly raised to normal levels (Lewis, 1966). For other diseases long-term studies were instituted to arrive at a better understanding of the state of health of the Islanders in the particular context of their unique isolated environment.

In some respects the Tristanians are fortunate; for example, there is no venereal disease (A. E. Wilkinson, private communication); there is very little cardiovascular disease and this prompted the undertaking of an extensive nutritional survey, which includes longitudinal studies of body-weight, skinfold thickness, serum lipids, energy expenditure and calorie intake.

This present paper on diet is part of the nutritional survey. Other studies will be published in the appropriate journals. The policy of the Medical Research Council working party is to collate the nutritional findings with findings from other fields, e.g. social anthropology, genetics, clinical medicine. It is hoped that this multidisciplinary survey of the health of the Tristan Islanders will be a continuing study.

Qualitative information about the diet in the last years on the Island and in the first few months in England was obtained by one of us (D.F.H.) and Dr P. J. Holloway. It was based on conversations with several of the Island women and some of the European staff (including the medical officer, Dr Samuels) who were on the Island at the time of the eruption. But none of the information obtained was sufficiently detailed to permit a quantitative assessment of the nutritional value of the diet. Means have, however, since been found to obtain quantitative information about the diet on the Island during the years immediately before the eruption and in England.

Records were obtained by the late $\mathrm{Mr} \mathrm{C}$. J. Lewis from the office of Tristan da Cunha Development Company in Cape Town, South Africa of all sales of foods through the island canteen on Tristan during the years 1958 to 1960 , and an assessment was made for us by Mr Lewis of the quantities bought by the Islanders (in distinction to the quantities bought by the resident European staff on the Island). Another assessment was made for us by $\mathrm{Mr} \mathrm{H}$. G. Stableford, of the quantities of 
home-produced foods consumed by the Islanders during those years; Mr Stableford was the Island's Agricultural Superintendent from 1953 to $195^{8}$. We are much indebted to both Mr Lewis and Mr Stableford for their help, which has led to the estimates given in Part I of this study.

The second part of this study was a survey of the family food consumption of most of the Islanders living in Calshot, Hants, in July 1963, made under the aegis of the Medical Research Council working party by one of us (E. C. T.) and a team of dietetic students from the Northern Polytechnic, London. The results of this survey are given in Part 2.

\section{PART I. Assessment of THE ISLANDERS' DIET ON TRISTAN DA CUNHA BEFORE THE VOLCANIC ERUPTION OF I96I}

\section{Experimental and results}

As no quantitative dietary survey had been made on Tristan da Cunha since that of the Norwegians in $1937-8$, we thought that an estimate of food consumption during the latter part of the last decade would be helpful for comparison with the diet of the Islanders in England. No direct inquiry was made. We must therefore emphasize that our estimates were based on observations that, at best, were of a deductive nature.

The Islanders renewed contact with the outside world in 1942 when a naval garrison was stationed on Tristan da Cunha. This did not play an important part in the life of the ordinary Islander, and it was not until the advent of the Tristan da Cunha Development Company in 1949 and the building of a factory for canning crayfish and crayfish tails that the opportunity occurred to re-establish island life on the basis of trade and a monetary economy. The Company was required by the terms of its concession to maintain a non-profit-making canteen on the Island; in 1956 its management was taken over by the Island Administration. At the canteen, Islanders spent about half their wages on groceries and most of the remainder on clothing (Colonial Office, 1952, I954, I956, I959, I961). The Islanders therefore obtained their food either as purchases from the canteen, or by producing it themselves. Local food supplies included potatoes, fish, eggs, birds, meat and vegetables. Small quantities of foods were also obtained by barter from passing ships at intermittent intervals.

From the canteen order books we extracted weights of all food items that had been purchased from 1958 to 1960 . There were approximately 260 Islanders (and 30 nonIslanders) living and working on Tristan da Cunha, and we estimated that the Islanders bought $85 \%$ of most of the foods sold in the canteen. Due allowance was made for the fact that they were not in the habit of eating luxuries such as asparagus tips and frozen strawberries. Further information on food bought from the canteen was obtained from the Islanders still resident in England in October I963, and we were able to adjust our estimates to comply with the preferences described. These Islanders said that no eggs were purchased and only small quantities of cheddar cheese, kippers and bacon.

Table I shows quantities of foods bought by Islanders from the canteen during 
$195^{8}$ to 1960 , expressed as oz/head per week, and for the 3 years both as oz and $\mathrm{g} / \mathrm{head}$ per week. The canteen became a very important source of food and one can only surmise that the Islanders must have fared very meagrely before it was opened.

By the terms of its concession the Development Company was also required to maintain an agriculturalist; it was recognized that if the Islanders worked for the

Table I. Purchases by Tristan da Cunha Isianders from the canteen 1958-60 inclusive

\begin{tabular}{|c|c|c|c|c|c|c|}
\hline \multirow{4}{*}{$\begin{array}{l}\text { Food } \\
\text { Milk, cream and cheese }\end{array}$} & & & & \multicolumn{2}{|c|}{$\overbrace{}^{\text {I 958-60 average }}$} & \multirow[b]{3}{*}{ Variety of foods purchased } \\
\hline & $195^{8}$ & 1959 & I96 & & g/head & \\
\hline & \multicolumn{3}{|c|}{ oz/head week } & week & week & \\
\hline & $5 \cdot 5$ & I9.4 & $17 \cdot 6$ & $14 \cdot 2$ & $4 \circ 3$ & $\begin{array}{l}\text { Evaporated condensed and dried } \\
\text { milk, canned cream, cheddar cheese }\end{array}$ \\
\hline Meat & $I \cdot I$ & 0.6 & 0.8 & 0.8 & 23 & $\begin{array}{l}\text { Beef, bacon, Vienna smoked sausage, } \\
\text { beef and pork sausages, canned } \\
\text { chicken, braised steak, pork lun- } \\
\text { cheon meat }\end{array}$ \\
\hline Fish & 0.9 & 0.7 & 0.8 & 0.8 & 23 & $\begin{array}{l}\text { Pickled fish, kippers, pilchards, } \\
\text { sardines }\end{array}$ \\
\hline Fats & $2 \cdot 4$ & $2 \cdot 0$ & $2 \cdot 1$ & $2 \cdot 2$ & 62 & $\begin{array}{l}\text { Butter, margarine, cooking oil, } \\
\text { cooking fat, lard }\end{array}$ \\
\hline Sugar & $7 \cdot 9$ & $9 \cdot I$ & $10 \cdot 2$ & $9 \cdot \mathbf{I}$ & 258 & 一 \\
\hline Preserves & 0.8 & $I \cdot I$ & $r \cdot 6$ & $\mathbf{I} \cdot \mathbf{I}$ & $3 r$ & $\begin{array}{l}\text { Honey, syrup, plum, peach, apricot, } \\
\text { strawberry, guava, melon and ginger } \\
\text { jam }\end{array}$ \\
\hline Vegetables & $2 \cdot I$ & $2 \cdot 3$ & I. 6 & $2 \cdot 0$ & 57 & $\begin{array}{l}\text { Butter beans, baked beans, canned } \\
\text { carrots, peas, beetroot, onions, } \\
\text { squash }\end{array}$ \\
\hline Fruit & $7 \cdot 1$ & 4.0 & $2 \cdot 3$ & 4.5 & 128 & $\begin{array}{l}\text { Oranges, apples, grapes, naartjies, } \\
\text { tomatoes, dates, dried vine fruit, } \\
\text { nuts, canned peaches, pears, pine- } \\
\text { apples }\end{array}$ \\
\hline Flour & $29 \cdot 7$ & $47 \cdot 8$ & $4 \cdot 4$ & $27 \cdot 3$ & 774 & $\begin{array}{l}\text { Bread, cake, brown and wholemeal } \\
\text { flour }\end{array}$ \\
\hline Other cereals & $4 \cdot 8$ & $2 \cdot I$ & $2 \cdot 8$ & $3 \cdot 2$ & $9 \mathrm{I}$ & $\begin{array}{l}\text { Rice, mealie meal, bread-crumbs, } \\
\text { biscuits, cake mixture, Ryvita, } \\
\text { macaroni, spaghetti, canned } \\
\text { spaghetti, custard powder, instant } \\
\text { puddings, breakfast cereals, oats, } \\
\text { pearl barley, }\end{array}$ \\
\hline Beverages & $1 \cdot 7$ & I'9 & $\mathrm{I} \cdot 4$ & $1 \cdot 7$ & 48 & Coffee, Nescafé, Ovaltine, tea \\
\hline $\begin{array}{l}\text { Soft drinks, wines, } \\
\text { spirits (fl. oz) }\end{array}$ & $7 \cdot 6$ & $19 \cdot 7$ & I $7 \cdot 0$ & $14 \cdot 8$ & 420 & $\begin{array}{l}\text { Lime juice, lemonade, Pepsi-cola, } \\
\text { beer, wine, champagne, sherry, } \\
\text { brandy, gin, whisky, rum }\end{array}$ \\
\hline Confectionery & 0.9 & $2 \cdot 2$ & $3 \cdot 1$ & $2 \cdot I$ & 60 & $\begin{array}{l}\text { Chocolate, pastilles, boiled sweets, } \\
\text { toffees, sugar beans }\end{array}$ \\
\hline Baby and health foods & 0.5 & 0.1 & 0.2 & $0 \cdot 3$ & 9 & $\begin{array}{l}\text { Farex, baby cereal, baby and junior } \\
\text { foods, Maltabella, cod-liver oil and } \\
\text { malt }\end{array}$ \\
\hline Miscellaneous & $3 \cdot I$ & $1 \cdot 7$ & $I \cdot 6$ & $2 \cdot I$ & 60 & $\begin{array}{l}\text { Salt, spices, baking powder, Bisto, } \\
\text { chutney, pickles, mayonnaise, } \\
\text { jelly cubes, sauces, Marmite, canned } \\
\text { and dehydrated soup }\end{array}$ \\
\hline
\end{tabular}



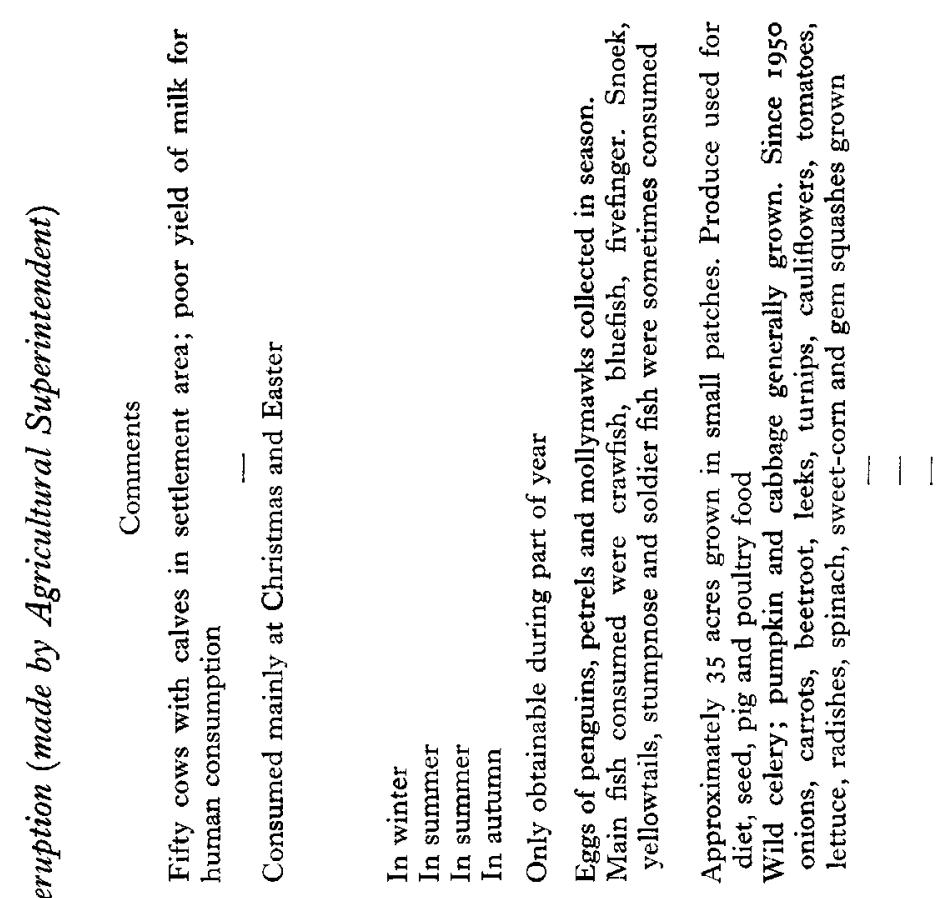

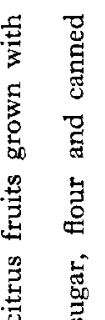

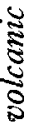

¿

\$

हैं

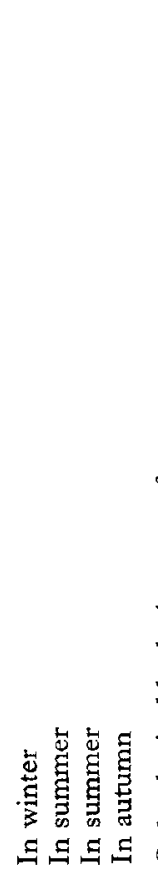

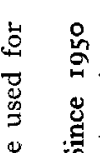

胥 㟥

要

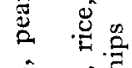
है

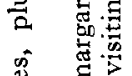

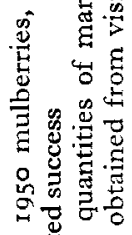

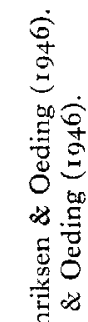

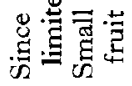

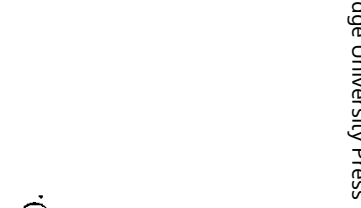

है:

공

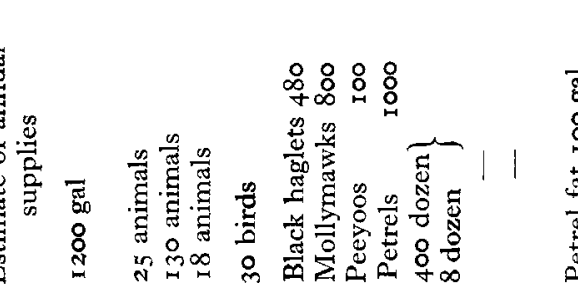

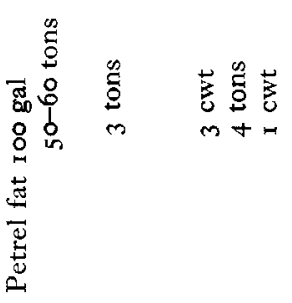

焉焉 
Company, they would have much less time to produce food for themselves; their husbandry was in any event poor and cattle were semi-starved in the winter. The Company therefore appointed an Agricultural Superintendent who advised the Islanders and ran a non-profit-making farm. He attempted to introduce new forms of vegetation to the Island and to improve the quality of the animals. Records of agricultural production were kept during the 195 os but these were lost at the time of the eruption. However, Mr Stableford provided us with an estimate of annual local food supplies as shown in columns 4 and 5 of Table 2 . We also used data obtained by the Norwegians to estimate annual consumption and nutrient content of fish and seabirds' eggs. We converted the annual estimates to their weekly equivalents expressed in $\mathrm{oz}$ and $\mathrm{g} /$ head of the Tristan population as shown in columns 2 and 3 of Table 2.

Table 3. Estimate (per head per day) of energy value and nutrient content of Tristan da Cunha Islanders' food supplies before the volcanic eruption

\begin{tabular}{|c|c|c|c|c|c|c|}
\hline Food source & $\begin{array}{c}\text { Energy } \\
\text { value } \\
\text { (kcal) }\end{array}$ & $\begin{array}{l}\text { Animal } \\
\text { protein } \\
\text { (g) }\end{array}$ & $\begin{array}{l}\text { Vegetable } \\
\text { protein } \\
\text { (g) }\end{array}$ & $\begin{array}{l}\text { Fat } \\
\text { (g) }\end{array}$ & $\begin{array}{c}\text { Carbohydrate } \\
\text { (g) }\end{array}$ & $\begin{array}{l}\text { Alcohol } \\
\text { (g) }\end{array}$ \\
\hline Local supplies & I 130 & 74 & 12 & 42 & 109 & - \\
\hline Canteen supplies & 900 & 7 & $I_{3}$ & 17 & 163 & 8 \\
\hline Total supplies & 2030 & $8 \mathrm{I}$ & 25 & 59 & 272 & 8 \\
\hline Percentage of energy value & & I6 & 5 & 26 & 50 & 3 \\
\hline
\end{tabular}

The nutrient equivalent of supplies from the two food sources was calculated and is shown in Table 3. For the most part we used the nutrient conversion factors prepared for the Ministry of Agriculture, Fisheries and Food as described in Appendix E of the National Food Survey Committee Annual Report for 1963 (Ministry of Agriculture, Fisheries and Food: National Food Survey Committee, 1965). The percentage of calories provided by animal and vegetable protein together was $2 \mathrm{I}$, about twice that found in most types of diet (Ministry of Health, 1964, Appendix 4); that from carbohydrate was similar to that found in most western European diets and that from fat considerably lower. The calorie value of the diet was typical of that reported for developing rather than developed countries (see, for example, FAO, 1962, p. 4).

At the time of the volcanic eruption, the island population, according to information from the Colonial Office, consisted of:

$\begin{array}{lcc}\text { No. of } & \begin{array}{c}\text { No. of } \\ \text { males }\end{array} & \text { females } \\ \text { Over 18 years } & 94 & 91 \\ \text { 6-18 years } & 22 & 26 \\ \text { Under 6 years } & 14 & 15 \\ \text { Total } & 130 & 132\end{array}$

From data from the FAO Report of the Second Committee on Calorie Requirements (FAO, 1957, p. 46) an average energy requirement of approximately $2400 \mathrm{kcal} /$ head per day was estimated, about $400 \mathrm{kcal}$ greater than the estimated intake given in Table 3 . 
PART 2. SURVEY OF THE FOOD CONSUMPTION OF FAMILIES FROM TRISTAN DA CUNHA DURING THEIR STAY IN ENGLAND

\section{Experimental}

Subjects. The dietary survey on the Tristan Islanders resident in Calshot, Hants took place between 28 June and I 2 July $1963,3-4$ months before their departure from England on 24 October 1963 .

This was the last of a series of investigations and, because it followed Press reports that had angered the community, great care was taken to introduce it in an acceptable way. A fortnight before the survey team arrived a member of the Department of Technical Co-operation (now the Ministry of Overseas Development), who was known to the Islanders, visited every household and sought their co-operation. Help was also enlisted from the area Health Visitor, the local branch of the Women's Voluntary Services and the vicar in whose parish Calshot lay. The Islanders trusted these people who encouraged them to take part in the study.

There was excellent co-operation from the majority of households, thanks to the good influence of the elderly women on their families. Four Islanders were completely hostile to the survey; they were responsible for major difficulties in five families who produced poor record books, and for minor difficulties with other subjects. The extent of the co-operation is shown below.

Living in Calshot

Agreement to co-operate in presurvey approach

Agreement to co-operate with interviewers

Records provided and reliable

Records provided and unreliable, but used in records of food purchases

Records classified as unreliable and not used

Records used for Tables 7 and 11

Records used for Tables 8 and 9

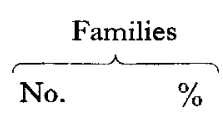

$41 \quad 100$

$40 \quad 98$

$37 \quad 90$

3 I

5

I

36

$\begin{array}{rr}\text { No. } & \% \\ 206 & 100 \\ 203 & 99 \\ 190 & 92 \\ 149 & 72 \\ 32 & 16 \\ 9 & \\ 181 & 48 \\ 149 & 72\end{array}$

The records were placed for analysis in four categories according to their reliability as assessed by the interviewers, taking into account the amount of weighing of food done, the co-operation of all members of the family, the observed intelligence and memory, and a detailed examination of the record for discrepancies or omission. The first group was made up of eighteen very good records judged by these criteria, the second of ten good ones and the third of three that were fairly good. The six records in the fourth group were unreliable, though all but one were considered satisfactory for inclusion in the calculation of average food purchases.

The composition of the households who co-operated in the survey is shown in Table 4, and the age and sex distribution of the survey population is compared in Table 5 with that of a British sample surveyed in the 3 rd quarter 1963 for the National Food Survey (Ministry of Agriculture, Fisheries and Food, unpublished). The proportion of subjects in the two groups was similar. The smaller percentage of men and women aged 2I-64 years in the Tristan group is explained by the composition of the 
Vol. 20

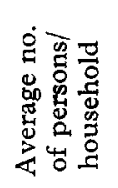

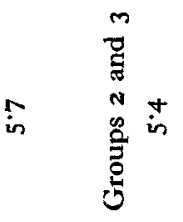

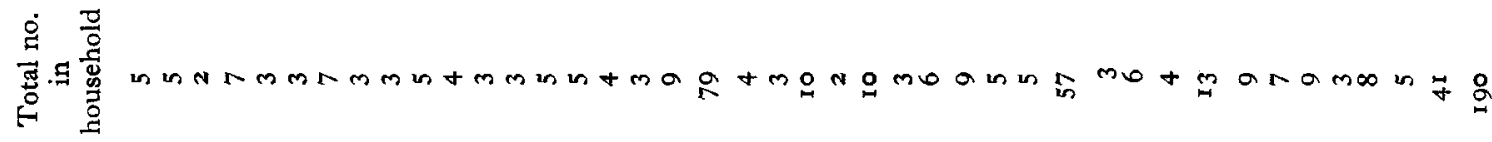

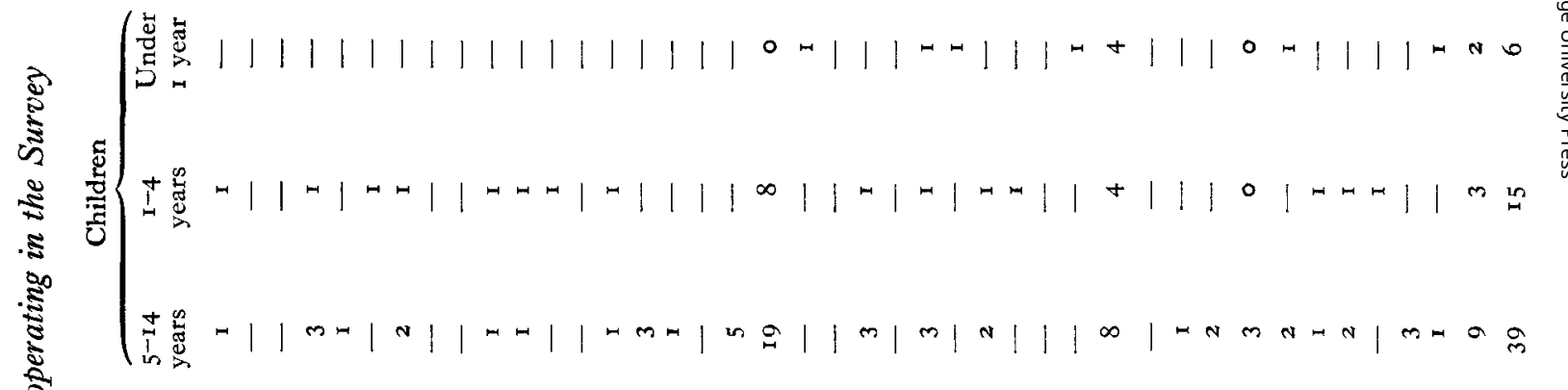

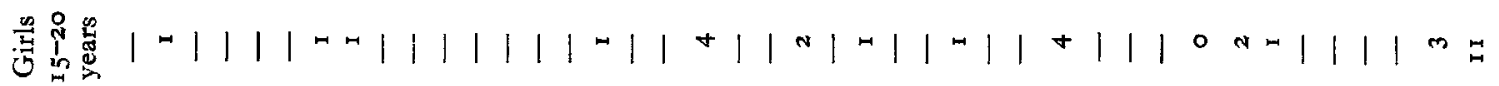

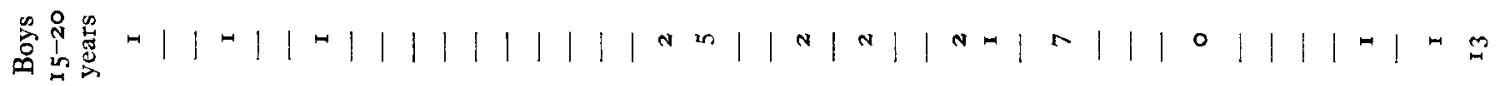

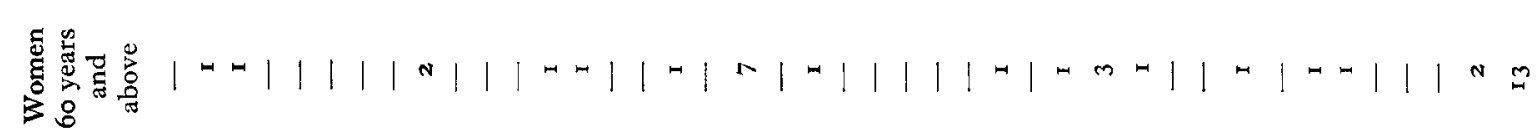

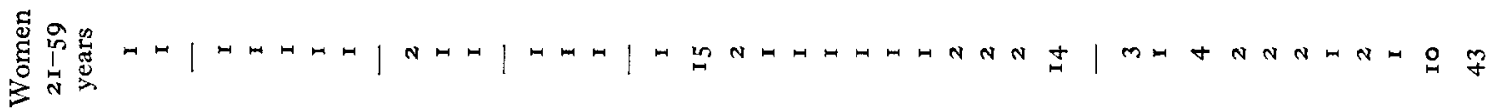
$\stackrel{+}{\stackrel{0}{0}}$

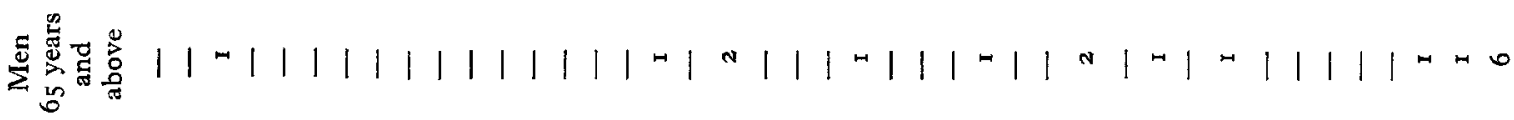

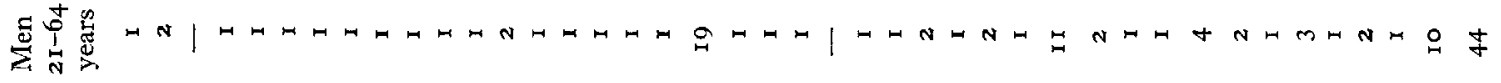

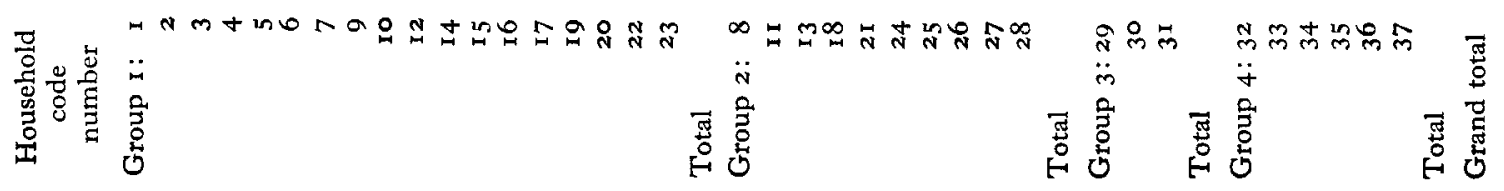


advance party, which returned to Tristan da Cunha in 1962 and was mainly drawn from this category. The total number of persons co-operating in the survey was 190 ; of these seventy-nine were in full-time employment, though seven were on holiday during the survey week, and thirty-six were schoolchildren. The main occupations are listed in Table 6 . Three of those on holiday were seamen with the Union Castle Line. One-half of the women in the $2 \mathrm{I}-59$ age group had full-time paid occupations and if they had children these were cared for by grandmothers during the day.

Table 5. Age and sex distribution of survey population (Comparison with National Food Surveys sample)

\begin{tabular}{|c|c|c|c|c|}
\hline & & No. & $\%$ & $\begin{array}{c}\% \text { (National } \\
\text { Food Survey } \\
\text { 3rd quarter } \\
\text { I } 963, \\
\text { unpublished) }\end{array}$ \\
\hline Men: & $\begin{array}{l}2 \mathrm{I}-64 \text { years } \\
65 \text { years and above }\end{array}$ & $\begin{array}{r}44 \\
6\end{array}$ & $\begin{array}{r}23 \cdot 2 \\
3 \cdot 2\end{array}$ & $\begin{array}{r}25^{\cdot 8} \\
4.0\end{array}$ \\
\hline Women: & $\begin{array}{l}21-59 \text { years } \\
60 \text { years and above }\end{array}$ & $\begin{array}{l}43 \\
\text { I3 }\end{array}$ & $\begin{array}{r}22 \cdot 6 \\
6 \cdot 8\end{array}$ & $\begin{array}{r}25 \cdot 9 \\
9 \cdot 2\end{array}$ \\
\hline Boys & $15^{-20}$ years & I3 & $6 \cdot 8$ & $4 \cdot 4$ \\
\hline Girls & $15-20$ years & I I & $5 \cdot 8$ & 4.2 \\
\hline Children: & $\begin{array}{l}5-14 \text { years } \\
\text { I-4 years } \\
\text { Under I year }\end{array}$ & $\begin{array}{r}39 \\
\text { I } 5 \\
6\end{array}$ & $\begin{array}{r}20.5 \\
7.9 \\
3.2\end{array}$ & $\begin{array}{r}16 \cdot 6 \\
7 \cdot 7 \\
2 \cdot 1\end{array}$ \\
\hline Total & & 190 & 100.0 & $99^{\circ} 9$ \\
\hline
\end{tabular}

Table 6. Main occupations of adult subjects

$\begin{array}{llr} & \text { No. of } & \text { No. of } \\ \text { Occupation } & \text { males } & \text { females }\end{array}$

Housewife
Factory worker
Labourer (roads, docks, oil refinery)
Waitress, dishwasher, cleaner
Attendant (car park, deck-chair)
Builder (house, boat)
Shop assistant
Gardener
Watchman
Garage mechanic
Carpenter
Apprentice
On holiday
Unemployed

The financial status of the families was difficult to judge; all but nine appeared able to enjoy all the necessities and some of the luxuries of life. The Islanders' homes were of a bungalow or terrace type in a compact Royal Air Force camp. They were generally well kept and furnished even to the extent of artificial flowers. By contrast, the gardens were neglected.

Measurement of food intake. The measurement of the total weekly food intake for 
each family entailed the weighing of larger stocks, i.e. every item of food in the house at the beginning and end of the survey; the daily recording of food purchases and gifts and the composition of each meal and the number of family and visitors present. Full details and, if possible, weights of all foods obtained and consumed outside the house were required. Questions were also asked about wastage. A Salter balance weighing up to ro $\mathrm{lb} \times \frac{1}{2} \mathrm{oz}$ was available for each family, but few would accept one. Each field worker carried a balance and did as much weighing as possible herself. There was also a larger scale for weighing sacks of potatoes. When foods were not weighed they were assessed by eye and by hand. Weights were often obtained from labels or by buying and weighing a similar article. Most of the Islanders took a midday snack from home but those who bought a meal described it, and quantities were assessed. The midday meals of schoolchildren were weighed at three separate schools.

Each family was provided with a log-book in which to record purchases and meals eaten at home. Every subject who was likely to purchase or receive food outside the home was instructed to record it in a notebook also provided. Every house was visited at least once daily at times convenient to the person who kept the record. An evening visit was necessary when working members refused to record their outside food consumption themselves. It was not always possible to assess or weigh foods before consumption and if the housewife would not use scales her estimate of quantities had to be accepted. Twenty-two families provided weighed records, eight others allowed weighing at the beginning and the end of the survey and seven allowed no weighing at all.

The nutrient equivalent of household food purchases consumed was calculated with the Ministry of Agriculture, Fisheries and Food conversion factors already referred to (described in Ministry of Agriculture, Fisheries and Food: National Food Survey Committee, $\mathrm{r}_{96}$, Appendix E); that for food eaten out was calculated for the most part from the tables of McCance \& Widdowson ( 1960 ); net values of $4,9,3.75$ and $7 \mathrm{kcal} / \mathrm{g}$ were assigned to protein, fat, carbohydrate (as glucose) and alcohol respectively. The nutrient equivalent of food consumed by visitors was deducted from the totals, but no deductions were made for edible wastage.

Calculation of requirements. For comparison with household food intake, estimates of nutrient requirements were made using the recommended dietary allowances of the British Medical Association: Committee on Nutrition (1950) as modified for use in the National Food Survey (Ministry of Agriculture, Fisheries and Food: National Food Survey Committee, r965, Appendix E, Table I). These allowances give only a broad indication of requirements and, as height and weight were not measured, the allocation of energy and nutrient requirements to each individual was difficult. For adults, placing in a category for energy requirement was determined by type and hours of work and by the general pattern of leisure activity; an individual of average build was placed in a category judged to be appropriate to his occupation, whereas one who appeared to be more heavily built was placed in the next highest category of energy requirement. Three-quarters of the women were classified as sedentary, i.e. with an energy requirement of $2100 \mathrm{kcal} /$ day. The remainder worked long hours or were 
Table 7. Household food consumption by Tristan da Cunha Islanders during survey week (Comparison with National Food Survey data for 3rd quarter, 1963)

\begin{tabular}{|c|c|c|c|c|c|c|}
\hline \multirow[b]{2}{*}{ Foods } & \multirow[b]{2}{*}{$\begin{array}{c}\text { No. of } \\
\text { households } \\
\text { purchasing }\end{array}$} & \multicolumn{2}{|c|}{$\begin{array}{l}\text { Quantity } \\
\text { consumed } \\
\text { by total } \\
\text { survey } \\
\text { population }\end{array}$} & \multicolumn{3}{|c|}{$\begin{array}{c}\text { National Food Survey, 3rd quarter } 1963 \\
\text { All households }\end{array}$} \\
\hline & & $\begin{array}{l}\text { oz/head } \\
\text { week }\end{array}$ & $\begin{array}{l}\text { g/head } \\
\text { week }\end{array}$ & $\begin{array}{l}\text { oz/head } \\
\text { week }\end{array}$ & $\begin{array}{c}\mathrm{g} / \text { head } \\
\text { week }\end{array}$ & \\
\hline Liquid milk & 30 & $24: 2$ & 690 & $96 \cdot 0$ & 2722 & \\
\hline Evaporated milk* & 35 & $40 \cdot 6$ & II 51 & 4.2 & I19 & \\
\hline Dried milk* & 7 & $6 \cdot 2$ & 176 & $2 \cdot 6$ & 74 & \\
\hline Cream & 12 & 0.4 & II & 0.6 & 17 & \\
\hline Cheese & 19 & 0.6 & 16 & $3 \cdot 2$ & 92 & \\
\hline Butter & 21 & $I \cdot 3$ & 37 & $6 \cdot 0$ & I69 & \\
\hline Margarine & 24 & $x \cdot 8$ & 50 & $3 \cdot 3$ & 94 & \\
\hline Dripping & 6 & 0.2 & 6 & 0.3 & 7 & \\
\hline Lard & 9 & 0.4 & 12 & $2 \cdot 0$ & 58 & \\
\hline Suet & 4 & $0 \cdot 1$ & 3 & 0.1 & 2 & \\
\hline Eggs & 32 & $5 \cdot 2$ & 147 & $9 \cdot 2$ & $26 I$ & \\
\hline Sugar & 36 & $12 \cdot 0$ & $34 \mathrm{I}$ & I9.0 & 537 & \\
\hline Preserves & 30 & $x \cdot 7$ & 47 & $3 \cdot 0$ & 85 & \\
\hline Beef & 28 & $8 \cdot I$ & 231 & $8 \cdot 9$ & 253 & \\
\hline Mutton & 33 & $\mathbf{I} 7 \cdot \mathbf{I}$ & 484 & $6 \cdot 9$ & 196 & \\
\hline Pork & 7 & $\mathbf{I} \cdot 0$ & 28 & $2 \cdot 2$ & 62 & \\
\hline Other meat & 28 & $5 \cdot 0$ & I 43 & $20 \cdot 0$ & 567 & \\
\hline Fish & 20 & $2 \cdot 9$ & 83 & $6 \cdot 2$ & I74 & \\
\hline Cabbage, cauliflower & 33 & $9 \cdot 3$ & 263 & $8 \cdot 5$ & $24 \mathrm{I}$ & \\
\hline Lettuce & 5 & $0 \cdot 2$ & 6 & $2 \cdot 4$ & 68 & (leafy salads) \\
\hline Broad beans and peas & 2 & 0.1 & 2 & $5 \cdot 7$ & 161 & $\begin{array}{l}\text { (beans fresh, peas quick- } \\
\text { frozen) }\end{array}$ \\
\hline Potatoes: old & 27 & $39^{\circ} 6$ & I 122 & $20 \cdot 0$ & 566 & \\
\hline new & 9 & $10 \cdot 2$ & 289 & $32 \cdot 4$ & 919 & \\
\hline Carrots & 9 & 0.5 & 14 & $2 \cdot 8$ & 79 & \\
\hline Onions & 34 & $2 \cdot 3$ & 66 & $2 \cdot 7$ & 77 & \\
\hline Other vegetables & 27 & $4 \cdot 1$ & 117 & $5 \cdot 3$ & I50 & $\begin{array}{l}\text { (canned peas, beans and } \\
\text { other canned vegetables) }\end{array}$ \\
\hline Apples & 17 & $2 \cdot I$ & 60 & $6 \cdot I$ & 174 & \\
\hline Oranges & 2 & 0.1 & 3 & $2 \cdot 2$ & 63 & \\
\hline Bananas & 5 & 0.4 & 10 & 3.7 & 106 & \\
\hline Strawberries & 4 & 0.2 & 7 & 3.0 & 86 & (soft fruit) \\
\hline Tomatoes & 9 & 0.8 & 22 & $6 \cdot 2$ & 175 & \\
\hline Other fruit & 33 & $5 * 9$ & 167 & 6.7 & 191 & (canned and dried fruit) \\
\hline Flour & 29 & $2 \cdot 3$ & 64 & $6 \cdot 3$ & 179 & \\
\hline Bread & 36 & $14 \cdot 5$ & 412 & $43 \cdot 5$ & 1233 & \\
\hline Cakes & $2 I$ & $\mathrm{r} \cdot 6$ & 44 & $6 \cdot 8$ & r93 & \\
\hline Biscuits & 35 & $3 \cdot 0$ & 84 & $5 \cdot 6$ & 159 & \\
\hline Oatmeal & 22 & $I \cdot 3$ & 37 & 0.5 & I5 & \\
\hline Breakfast cereals & 12 & 0.4 & 12 & $2 \cdot 3$ & 64 & \\
\hline Rice & 20 & $\mathbf{I} \cdot 0$ & 29 & 0.6 & 17 & \\
\hline $\begin{array}{l}\text { Other cereals and } \\
\text { puddings }\end{array}$ & 28 & $x \cdot 7$ & 49 & $3^{\cdot 6}$ & 102 & \\
\hline Tea & 36 & $\mathrm{I} \cdot 8$ & $5^{r}$ & $2 \cdot 8$ & 80 & \\
\hline Coffee & 20 & 0.2 & 7 & 0.4 & 12 & $\begin{array}{l}\text { (powders, crystals and } \\
\text { essences) }\end{array}$ \\
\hline Other beverages & 12 & 0.2 & 5 & 0.3 & 9 & \\
\hline Jelly† & 20 & 0.8 & 23 & 0.6 & 16 & \\
\hline Miscellaneous & 30 & $2 \cdot 0$ & 58 & $4 \% 4$ & 125 & \\
\hline
\end{tabular}


particularly busy or overweight housewives; they were classified as moderately active with a requirement of $2500 \mathrm{kcal} / \mathrm{day}$. None of the men was classified as very active, the highest adult male energy requirement being judged to be $3500 \mathrm{kcal} / \mathrm{day}$. The children were classified according to age as in the same adaptation of the British Medical Association's recommendations, a procedure that may have led to an overestimate of energy requirements because the Tristan children were smaller and weighed less than British children of similar age. The calculated energy and nutrient requirements are far in excess of recorded intake.

\section{Results}

The analysis was made in terms of household food purchases and food bought and eaten away from home. School meals and milk comprised the greater proportion of meals eaten out, but sweets, ice-cream, snacks and alcoholic drinks were also recorded.

Table 7 shows the quantities of foods consumed during the survey week by Tristan Islanders compared with similar values for British households surveyed for the National Food Survey between July and September 1963 (Ministry of Agriculture Fisheries and Food, unpublished). The Tristanians recorded a lower consumption of nearly all foods, and particularly of bread. They appeared to prefer evaporated to fresh milk, but this may have been a habit of the adults as most of the children drank school milk. Relatively small amounts of sugar and preserves were consumed, but these were greater than the quantities recorded before they left the Island (cf. Table I). Mutton was eaten in large quantities but it was mainly of stewing quality. "Tristan meat pie' was a version of Irish stew, 'Tristan soup' was a watery stew and 'Tristan smash' was corned beef hash. Roast and fried meat were often boiled first because the cuts were cheap and would not cook quickly. The Islanders did not like fish as sold in England and little was eaten, though it was sometimes prepared as a hash with potatoes and onion. Similar quantities of potatoes and cabbage were consumed by Tristan and British households, but few other vegetables were eaten in any quantities by the Islanders. In July nearly all the potatoes eaten in British households were new (Ministry of Agriculture, Fisheries and Food, unpublished monthly records), whereas threequarters of the Islanders' purchases were of old tubers. Little fresh fruit was eaten, but canned fruits, especially peaches and pineapple, were popular; jelly was also popular, as it had been on the Island, but other desserts were seldom eaten. Tea was the most popular drink. It was taken very sweet and with evaporated milk. All visitors were offered tea and biscuits and, on special occasions, sherry and cakes.

Table 8 shows the mean daily energy value and nutrient content of the diet of the households in group I, groups 2 and 3 together and in groups 1,2 and 3 together. In this analysis, in order to calculate standard deviations, intakes were calculated for each household and were expressed per head for each household; the averages shown are the arithmetic means of these intakes per head. Mean intake per head was greater in group I, in which families were, on average, smaller than in groups 2 and 3 , though variation within the groups was considerable. Data for the larger families are the more 


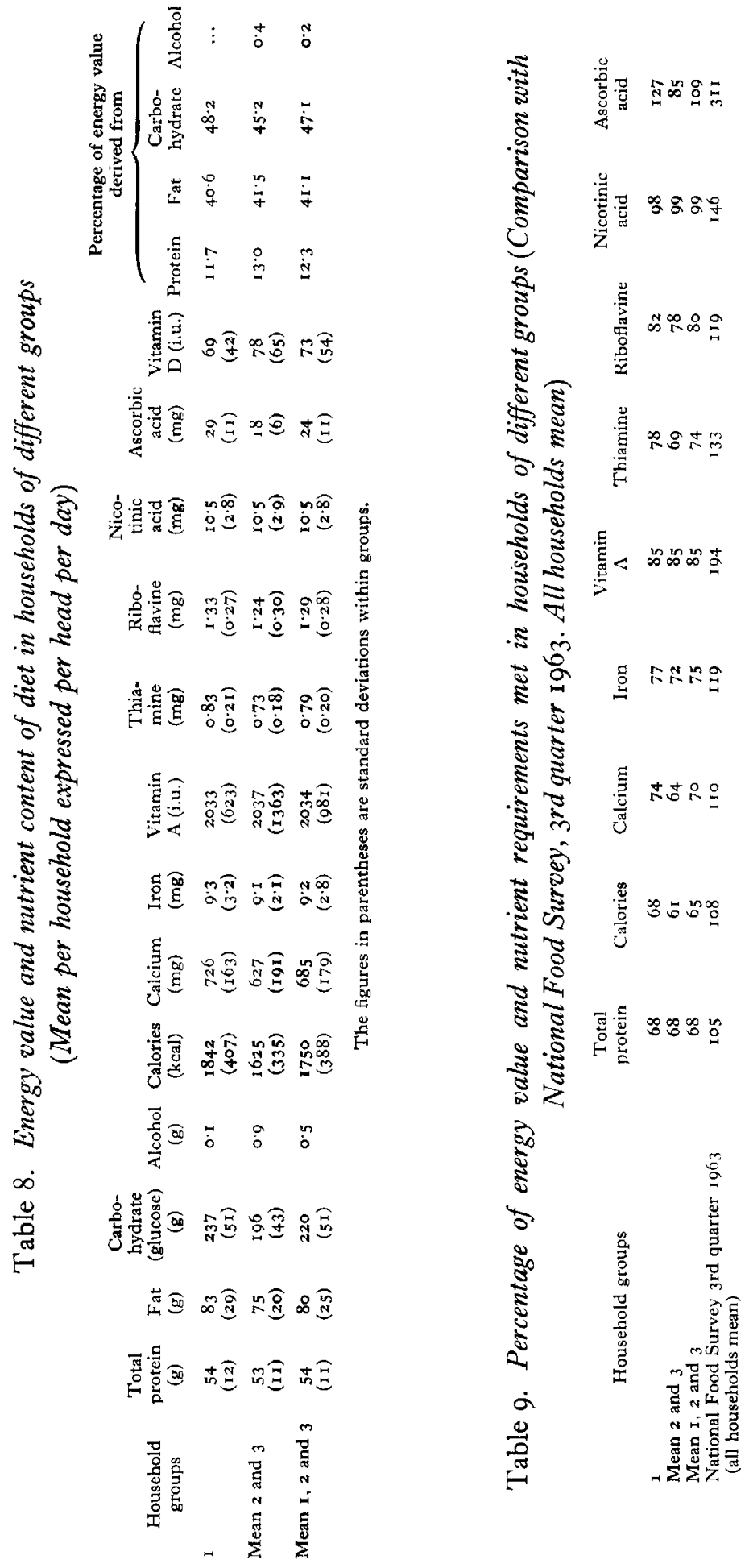


unreliable because it was difficult to obtain information from every member of the household on food eaten outside the home.

The intake of calories and nutrients appeared to be low, and we decided to compare them with the results of the National Food Survey for July to September 1963. In making this comparison the Tristan data were treated exactly as those of the National Food Survey (as described in Appendix E of the Annual Report for 1963-Ministry of Agriculture, Fisheries and Food: National Food Survey Committee, 1965); that is, I0\% was deducted from the nutritional value of the intake of the whole of group I, groups 2 and 3 together and groups 1,2 and 3 together for comparison with the estimates of the requirements of all the persons in each classification. Table 9 gives the results of this comparison and the corresponding one for the National Food

Table ıо. Consumption of main snacks and alcoholic beverages outside the home

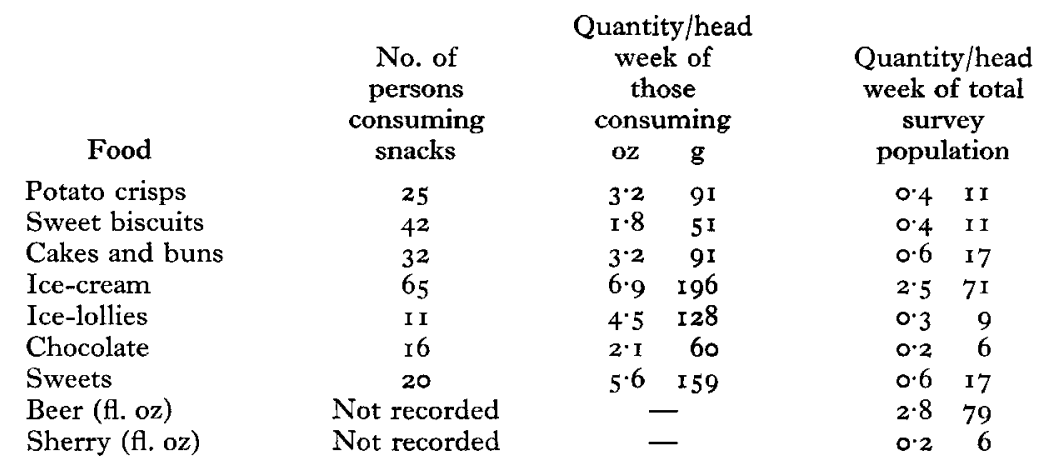

Survey households. The Tristanians met only $65 \%$ of estimated energy requirements compared with $108 \%$ of British households, and there were similar differences for other nutrients. The percentages of energy value provided by protein, fat and carbohydrate (Table 8) were much closer to those in British diets than the corresponding percentages discussed in relation to Table 3. It appeared, therefore, that although when he was in England in June/July I 963 the average Islander consumed much less than an average British person, the balance of his diet had changed considerably since he left Tristan, and approached that usual in Britain. The Tristan and British diets were found to be almost identical in composition if expressed per rooo kcal, except for vitamin $A$ and ascorbic acid, which were considerably lower in the Tristan diet, I200 i.u. vitamin $A$ and $\mathrm{I}_{4} \mathrm{mg}$ ascorbic acid/rooo kcal compared with 1700 i.u. and $26 \mathrm{mg}$ respectively.

The main snacks and alcoholic beverages taken outside the home are listed in Table Io. The Tristan children were the chief consumers of ice-cream, ice-lollies, chocolates and sweets; the quantities indicate that the mean weekly intake per child amounted to three and a half portions of ice-cream and two ice-lollies in addition to $2 \mathrm{oz}$ of chocolate and $5^{\frac{1}{2}} \mathrm{oz}$ of other sweets. Most of the potato crips, sweet biscuits, and cake were bought in factory canteens. The recorded consumption of alcoholic drinks was not high. 


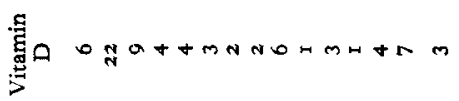

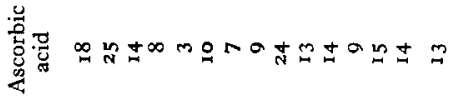

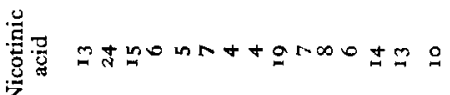

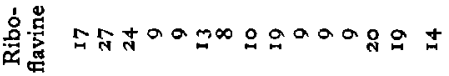

莺

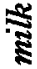

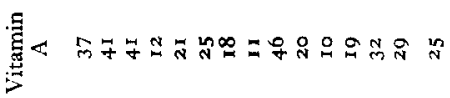

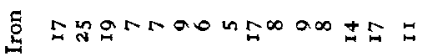

ङ है

\&

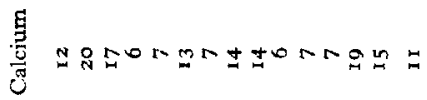

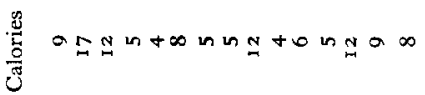

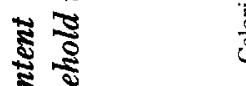

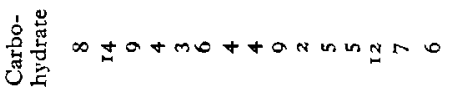

迹

కี

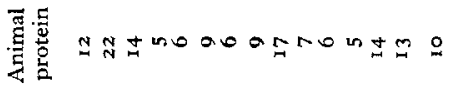

$\frac{2}{2}$

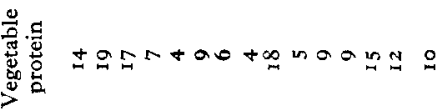

डे

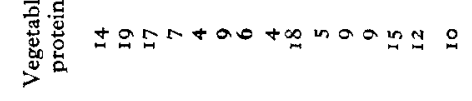

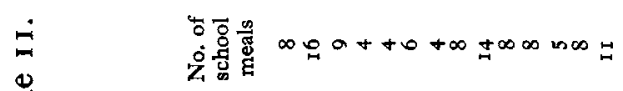

$\frac{\mathscr{D}}{0}$

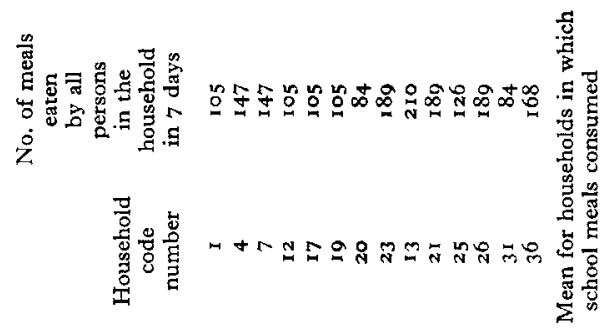


The energy value and nutrient content of school meals and milk expressed as a percentage of total household intake is shown in Table I I. In the households in which school meals were taken, school meals and milk contributed $25 \%$ vitamin A, $20 \%$ protein and more than $10 \%$ calcium, iron, thiamine, riboflavine and ascorbic acid to the total nutrient intake. This substantiates the impression gained by one of us (E.C.T.) that the children relied heavily on these meals and that the quantities of protein foods for the main evening meals were not sufficient to provide portions for them.

\section{DISCUSSION}

The small intake of energy and other nutrients by the Tristan people is the most striking of the dietary survey findings. This encourages speculation in several directions.

There may have been an overestimate of requirements, particularly for children and young people, but even if this were so it would not explain completely the low food intake. The children were in general small and weighed less than those of similar age in Britain (Black et al. 1963 ), but the boys appeared to catch up in later life and achieved average and above-average height, although the majority remained lean. The women, on the other hand, had a small and stockier appearance and several elderly women were obese.

A number of factors could have reduced the actual food purchases of the Islanders. Since their departure from England was imminent, some families may have been tempted to cut down on food purchases in order to buy other items to take back to Tristan; indeed six families stated that they were doing so. In three families, purchases were reduced because the head of the household was unemployed, and in four others a woman member was attempting to reduce weight. There was evidence that the Islanders did not like the potatoes and fish they could buy in England; they thought their cost excessive and the flavours much inferior to those of the same foods on Tristan. It appeared that they had not changed adequately from a diet in which these were the staple foods. In addition, canned foods, apart from evaporated milk, were not popular with the older people although used by the younger families; this dislike apparently stemmed from an outbreak of food poisoning on Tristan that the subjects said had been caused by canned corned beef.

The meal pattern of the Islanders, which showed little variation between households, indicated a small total intake of food. Only five families had a cooked or cereal type of breakfast regularly; the remainder normally took a small quantity of bread and tea or often tea alone. Over half the community had a midday meal away from home, but, except for the children who had school meals, this was only a snack. Those having their midday meal at home ate bread or sandwiches and tea unless young children were present, in which event a meal was cooked.

Wastage of edible food might affect the results, but, even if no food was wasted, all but five families apparently consumed less than their calculated requirements. The Islanders said they wasted much less food in England than on Tristan, chiefly because of the cost. 
Difficulties were encountered in the field which possibly led to underestimates of some foodstuffs. Some of these are common to surveys on British samples and included the storage of foodstuffs in several places in the house, frequent shopping by all members of the family at conveniently placed local stores and travelling vans, omission of records of snacks and the notorious difficulty of obtaining details of alcohol consumption. There were, however, others peculiar to the Islanders, such as widespread suspicion that their word was distrusted when weighing was done, a frequent confusion of cost with weight especially with meat and vegetables (e.g. $2 s .6 d$. worth of meat described as $2 \frac{1}{2} \mathrm{lb}$ ) and a real reluctance to mention food given to visitors, presumably because this would have sounded inhospitable. Visiting was the most popular pursuit of the Tristan people and in the evenings the homes possessing television sets were crowded, making information about diets difficult to obtain. The younger people enjoyed dancing at the local 'Esso' club, and the bars of the nearby hotels were well-frequented.

The field workers did their best in spite of these difficulties to get accurate records and did not think that those judged to be reliable were underestimates of what was eaten at the time of the survey. Indeed, except for those who were reducing their food purchases deliberately, the subjects said that their intake during the survey week was typical of their normal habits in England. The observation that the Islanders appeared to eat a relatively small amount of food conforms with the findings of the Norwegian investigation in 1937-8 (Henriksen \& Oeding, 1946) and with our own calculations on the food supplies available on the Island immediately before the eruption (Part I), but in the absence of tests by validity such as measurements of weight changes and activity, it is impossible to draw firm conclusions.

Unfortunately, it was not possible to study the energy expenditure of individual Islanders at the time of the Calshot survey, and although soon after their arrival in England in 1961 weights of some Islanders were obtained, covering the entire age range, they could not be re-weighed before they returned to Tristan da Cunha. There is, therefore, no way of finding out whether low family intake of calories meant that the Islanders were living in a permanent state of negative calorie balance and so losing weight while they were in England.

\section{Conclusion}

Casual observation suggested that the Islanders were not losing weight, and the tentative conclusion to be reached can hardly be other than that their energy expenditure in England was lower than that of the British population. No measurements have been made of the energy expenditure of members of the community on the Island, but the fact that the energy intake appeared to be low there as in England suggests that they may not be very active. In view of the reports in all accounts of life on Tristan of the great potential for physical activity, at least by the men, it would be of considerable interest if energy balance studies on individual men, women and children could be made on Tristan when the Islanders have settled down again to their traditional pattern of life. 
The arrangements for this family food survey were, by nature, complex, and its success depended particularly on the goodwill and generosity of many people. The authors have pleasure in warmly acknowledging their help. They were: The Tristan Islanders; Miss Jean Marr, Medical Research Council, London Hospital Department of Social Medicine; Department of Catering, Dietetics and Domestic Science, The Northern Polytechnic, London, N 7. Staff: Mrs J. A. Gibbins, Mrs A. R. Nilson; Students: Misses A. D. Forster, A. E. Lace, J. M. McLeod, E. J. W. Martin, V. Ng, L. E. Parry, J. M. Southcott, A. B. Thompstone, S. J. Vale and Mrs P. Parkinson; Mrs M. Kemp, Area Health Visitor; Hythe Branch of the WVS: The Mesdames Boots, Davage, Davies, Drodge, Gardner, Garle, Ide, McDonald, Smith and Thomas; The Rev. N. Brewster; Mr Young, Headmaster, Hardley Secondary Modern School; $\mathrm{Mr}$ Liddell, Headmaster, Fawley Primary School; Mr Whitefield and Mr Wellman of the Colonial Office; Mr H. G. Stableford, Agricultural Superintendent, Tristan da Cunha 1953-8; Lt Col J. M. Adam, RAMC, Division of Human Physiology, and staff at National Institute for Medical Research, Hampstead, NW 3.

The survey was initiated and supported by the Tristan da Cunha Working Party of the Medical Research Council. One of the authors (E.C.T.) was in receipt of a Medical Research Council grant. Requests for reprints should be addressed to D.F.H.

\section{REFERENCES}

Barnes, H. N. V. (1937). Br. dent. F. 63, 86.

Black, J. A., Thacker, C. K. M., Lewis, H. E. \& Thould, A. K. (1963). Supplement, Br. med. F. ii, IоI 8. British Medical Association: Committee on Nutrition (1950). Report of the Committee on Nutrition. London: British Medical Association.

Citron, K. M. \& Pepys, J. (1964). Br. F. Dis. Chest. 58, I I9.

Colonial Office (I 952). Report on St Helena for the years 1950 and 195 I. London: H.M. Stationery Office. Colonial Office (1954). Report on St Helena for the years 1952 and 1953 . London: H.M. Stationary Office. Colonial Office (1956). Report on St Helena for the years 1954 and 1955. London: H.M. Stationery Office.

Colonial Office (1959). Report on St Helena for the years 1956 and 1957. London: H.M. Stationery Office.

Colonial Office (1961). Report on St Helena for the years 1958 and 1959 . London: H.M. Stationery Office. Drummond, J. C. \& Wilbraham, A. (1939). The Englishman's Food, ist ed. London: Jonathon Cape.

FAO: Second Committee on Calorie Requirements (1957). F.A.O. nutr. stud. no. I 5.

FAO (I962). Statistics of Hunger. Rome.

Henriksen, S. D. \& Oeding, P. (1946). In Results of the Norwegian Scientific Expedition to Tristan da Cunha 1937-1938. Vol. I, no. 5. [E. Christopersen, editor.] Oslo: Dybwad.

Holloway, P. J., James, P. M. C. \& Slack, G. L. (1963). Br. dent. F. rr5, r9.

King-Turner, E. W. \& Davies, P. (1956). Br. dent. F. ror, 262.

Lewis, H. E. (1963). New Scient. 20, 720 .

Lewis, S. M. (1966). Israel F. med. sci. (In the Press.)

McCance, R. A. \& Widdowson, E. M (1960). Spec. Rep. Ser. med. Res. Coun. no. 297.

Ministry of Agriculture, Fisheries and Food: National Food Survey Committee (1965). Domestic Food Consumption and Expenditure: 1963 . London: H.M. Stationery Office.

Ministry of Health (I964). Reports on Public Health and Medical Subjects no. I I I. Requirements of Man for Protein. London: H.M. Stationery Office.

Sakula, A. (1963). Tubercle, Lond. 44, 225.

Sampson, W. E. A. (1932). Br. dent. F. 53, 397.

Samuels, N. (1963). Br. med. F. ii, ror 3 .

Soggnaes, R. F. (1954). In Results of the Norwegian Scientific Expedition to Tristan da Cunha $1937-1938$. Vol. I, no. 24. [E. Christopersen, editor.] Oslo: Dybwad.

Thacker, C. K. (1963). Trans. R. Soc. trop. Med. Hyg. 57, 10.

Woolley, E. J. S. (1946). $\mathscr{l} R$. nav. med. Serv. 32, 3. 